\title{
Tipoexm SWorld
}

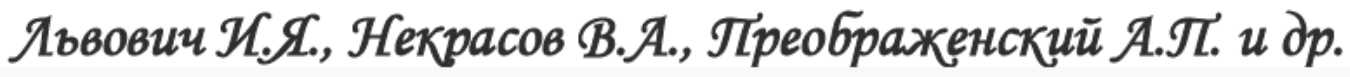

\section{ПЕРСПЕКТИВНЫЕ ТРЕНДЫ РАЗВИТИЯ НАУКИ: ТЕХНИКА И ТЕХНОЛОГИИ}

входит в РИНЦ SCIENCE INDEX

присвоен DOI: 10.21893/978-966-2769-88-3

\section{МОНОТРАФНЯ}

Книга 1 
ББК 94

П 278

Авторский коллектив:

Львович И.Я. (2.), Некрасов В.А. (3.), Преображенский А.П. (2.), Чопоров О.Н. (2.), Бобось О.Л. (1.), Абрамова Л.С. (6.), Антоненко А.В. (1.), Бондаренко А.В. (3.), Бровенко Т.В. (1.), Копей Б.В. (4.), Птица Г.Г. (6.), Бородин А.В. (5.), Федоляк Н.В. (4.), Довга О.О. (1.), Ліфіренко О.С. (1.), Лях М.М. (4.), Михайлик В.С. (1.), Стукальська Н.М. (1.)

Рецензенты:

Нагорный Евгений Васильевич, д.т.н., профессор, зав. каф. "Транспортных технологий", Харьковский национальный автомобильно-дорожный университет

Кониур Іван Федорович, канд.техн.наук, доцент, ІФНТУНГ

Кострова Вера Николаесна, доктор технических наук, профессор, проректор, Воронежский институт высоких технологий

Коробанов Юрий Николаевич, доктор технических наук, профессор, Национальный университет кораблестроения имени адмирала Макарова

П 278 Перспективные тренды развития науки: техника и технологии. В 2 книгах. К 1.: монография / [авт.кол. : Львович И.Я., Некрасов В.А., Преображенский А.П. и др.]. - Одесса: КУПРИЕНКО СВ, 2016 - 197 с. : ил., табл.

ISBN 978-966-2769-88-3

Монография содержит научные исследования авторов в области техники и технологий. Может быть полезна для инженеров, руководителей и других работников предприятий и организаций, а также преподавателей, соискателей, аспирантов, магистрантов и студентов высших учебных заведений.

\section{УДК 001.895 \\ ББК 94 \\ DOI: $10.21893 / 978-966-2769-88-3$}

ISBN 978-966-2769-88-3

(C) Коллектив авторов, 2016

(C) Куприенко С.В., оформление, 2016 


\section{Монограбия подготовлена авторским коллективом:}

1. Львович Игорь Яковлевич, Паньевропейский университет, доктор технических наук, профессор - ГЛАВА 2. (в соавторстве)

2. Некрасов Валерий Александрович, Національний університет кораблебудування ім. Адмірала Макарова, кафедра теории и проектирования судов, доктор технических наук, профессор - ГЛАВА 3. (в соавторстве)

3. Преображенский Андрей Петрович, Воронежский институт высоких технологий, доктор технических наук, доцент - ГЛАВА 2. (в соавторстве)

4. Чопоров Олег Николаевич, Воронежский институт высоких технологий, доктор технических наук, профессор - ГЛАВА 2. (в соавторстве)

5. Копей Богдан Володимирович, Івано-Франківський національний технічний університет нафти і газу, Кафедра нафтогазового обладнання, доктор технических наук, профессор - ГЛАВА 4. (в соавторстве)

6. Бобось Олександр Леонідович, кафедра технологіїі і організації ресторанного господарства, кандидат ветеринарных наук - ГЛАВА 1. (в соавторстве)

7. Абрамова Людмила Сергеевна, Харьковский национальный автомобильнодорожный университет, кафедра "Организации и безопасности дорожного движения", кандидат технических наук, доцент - ГЛАВА 6. (в соавторстве)

8. Антоненко Артем Васильович, кафедра готельно-ресторанного бізнесу, кандидат технических наук - ГЛАВА 1. (в соавторстве)

9. Бондаренко Александр Валентинович, Національний університет кораблебудування ім. Адмірала Макарова, кафедра теории и проектирования судов, кандидат технических наук, доцент - ГЛАВА 3. (в соавторстве)

10.Бровенко Тетяна Вікторівна, кафедра готельно-ресторанного бізнесу, кандидат технических наук - ГЛАВА 1. (в соавторстве)

11.Птища Геннадий Григорьевич, Харьковский национальный автомобильнодорожный университет, кафедра "Организации и безопасности дорожного движения", кандидат технических наук, ст. преп - ГЛАВА 6. (в соавторстве)

12.Бородин Андрей Викторович, Поволжский государственный технологический университет, кафедра Информатики и системного программирования, кандидат экономических наук, профессор - ГЛАВА 5.

13. Федоляк Неля Василівна, Івано-Франківський національний технічний університет нафти i газу, Кафедра нафтогазового обладнання, специалист ГЛАВА 4. (в соавторстве)

14.Довга Олена Олександрівна, кафедра готельно-ресторанного бізнесу ГЛАВА 1. (в соавторстве)

15. Ліфіренко Олена Сергївна, кафедра готельно-ресторанного бізнесу ГЛАВА 1. (в соавторстве)

16.Лях Михайло Михайлович, Івано-Франківський національний технічний університет нафти і газу, Кафедра нафтогазового обладнання, профессор ГЛАВА 4. (в соавторстве)

17. Михайлик Валентин Сергійович, кафедра технологіїі і організації ресторанного господарства - ГЛАВА 1. (в соавторстве)

18. Стукальська Наталія Миколаївна, кафедра туристичного та готельного бізнесу ГЛАВА 1. (в соавторстве) 


\section{Содержание}

\section{ГЛАВА 1. ІННОВАЦІЙНІ ТЕХНОЛОГІЇ СОУСІВ 3 БІОЛОГІЧНОАКТИВНИМИ КОМПОНЕНТАМИ}

Вступ....

1.1. Теоретичні та практичні аспекти створення соусів з біологічно активними компонентами як продукту функціонального призначення...................................................6

1.2. Наукове обгрунтування і розроблення соусів з біологічно активними компонентами.................................................. 37

1.3. Соціально-економічна ефективність та конкуренто придатність соусів

Висновки .72

\section{ГЛАВА 2. РАЗРАБОТКА ИНФОРМАЦИОННОЙ СИСТЕМЫ УПРАВЛЕНИЯ ПРОЕКТАМИ В ОРГАНИЗАЦИИ}

Введение......................................................73

2.1. Характеристики проектов в организации............................... 73

2.1.1. Основные элементы управления проектами ......................73

2.1.2. Структура проекта.........................................74

2.1.3. Средства групповой работы для корпораџии и база данных для отслеживания переговоров..................................... 78

2.2. Автоматизированное рабочее место менеджера управления проектами...........................................................79

2.2.1. Автоматизированное рабочее место (АРМ): понятие, принципы построения...........................................78

2.2.2. Этапы разработки и моделирования АРМ менеджера управления проектами .............................................82

2.2.3. Принщипы построения АРМ менеджера и требования, предъявляемые к ним ...........................................84

2.3. Разработка системы управления проектами...........................91

2.3.1. Обоснование требований и выбор средств реализации.............91

2.3.2. Структура разрабатываемой системы.........................992

2.3.3 Разработанный программный продукт.........................92

\section{ГЛАВА З. КОНЦЕПЦІЯ КОМПЛЕКСНОГО ОЦІНЮВАННЯ ЕФЕКТИВНОСТІ ТА НАДІЙНОСТІ КОРАБЛІВ БЕРЕГОВОЇ ОХОРОНИ}

Вступ....

3.1. Концепція комплексного оцінювання ефективності та надійності корабля берегової оборони ...

3.2. Модель функціонування корабля берегової охорони 103 
3.2.1. Модель функиіонування КБО при моделюванні місії 3 дотримання правового режиму та запобігання загрозам $(E L T)$

3.2.2. Модель функціонування КБО при моделюванні пошуковорятувальної місії (SAR).

3.2.3. Модель функціонування КБО при моделюванні місії з охорони довкілля, боротьби із забрудненням моря (МЕР)

3.2.4. Модель функціонування КБО при моделюванні місії з військового застосування (MR)

Висновки.

\section{ГЛАВА 4. МОБІЛЬНІ ЦИРКУЛЯЦІЙНІ СИСТЕМИ УСТАНОВОК ДЛЯ БУРІННЯ І КАПІТАЛЬНОГО РЕМОНТУ СВЕРДЛОВИН}

Вступ...........................................................

4.1. Вимоги до комплектності мобільних циркуляційних систем..........124

4.2. Дослідження з вибору обладнання циркуляційних систем.............125

4.3. Аналіз залежності об'єму циркуляційної системи від глибини

буріння свердловини............................................ 143

Висновки..........................................................

\section{ГЛАВА 5. МЕТОДЫ ОБФУСКАЦИИ ПРОГРАММ НА ОСНОВЕ ПСЕВДОСЛУЧАЙНОЙ ТРАНСФОРМАЦИИ ПОТОКА УПРАВЛЕНИЯ}

Введение 145

5.1. Формальное понимание обфускации.............................. 146

5.2. Современная практика обфускации................................... 149

5.3. Идея предлагаемого подхода........................................ 149

5.4. Алгоритм предлагаемого метода обфускации в целом................151

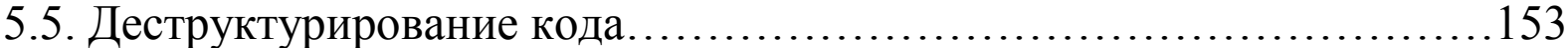

5.6. Обфускация кода.................................................. 157

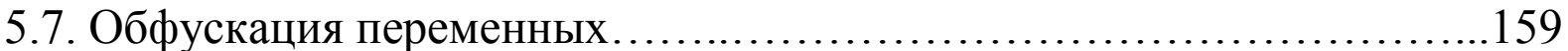

5.8. Обфускация констант.............................................. 162

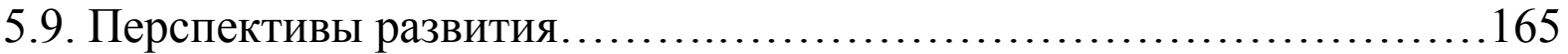

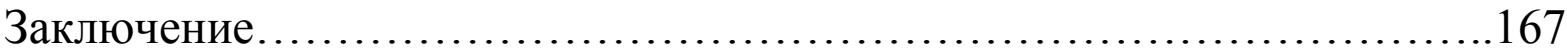

\section{ГЛАВА б. КОНЦЕПЦИЯ УПРАВЛЕНИЯ БЕЗОПАСНОСТЬЮ ДОРОЖНОГО ДВИЖЕНИЯ}

Введение. 168

6.1. Анализ уровня безопасности дорожного движения.....................169

6.2. Анализ рисков в дорожном движении.............................. 171

6.3. Анализ этапов управления безопасностью дорожного движения....................................................174

6.4. Классификация и анализ методов определения уровня безопасности дорожного движения.................................. 179

Выводы............................................................... 188

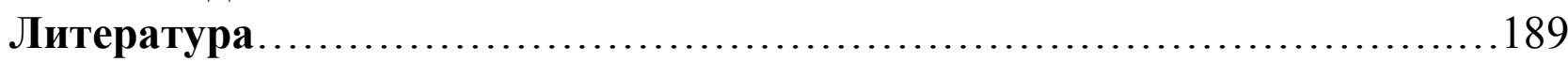




\section{Aumepamypa}

Глава 1:

1. Богатырев А. Использование БАД в пищевых продуктах / А. Богатырев, О. Большаков // Пищевая промышленность. - 1997. - №9. - С.25-27.

2. Бабенко Г.А. Микроэлементозы человека: патогенез, профилактика, лечение / Г.А. Бабенко // Микроэлементы в медицине. -2001. -Т.2 . - №1. -С. 2-5.

3. Азгальдов Г.Г. О квалиметрии / Г.Г. Азгальдов, Э.П. Райхман. - М.: Изд-во стандартов, 1973.

4. Адлер Ю.П. Планирование эксперимента при поиске оптимальных условий / Ю.П. Адлер, Е.В. Маркова, Ю.В. Грановский. - Москва: Изд-во Наука, 1971.- 282 с.

5. Авцын А.П. Микроэлементы человека: этиология, классификация, органопатология / Авцын А.П., Жаворонков А.А., Риш М.А., Сторчкова А.С. М.: Медицина, 1991. - 496 с.

6. Василевская Л.С. Физиологические основы питання /Л.С. Василевская, Л.Г. Охинянская // Вопросы питания. - 2002. - №2. - С. 42-45.

7. Смоляр В.И. Рациональное питание / В.И. Смоляр. - К.: Наук. думка, 1991.-368 c.

8. Спиричев В.Б. Обогащение пищевых продуктов микронутриентами: научные подходы и практические решения / В.Б. Спиричев, Л.Н. Шатнюк, В.М. Позняковский // Пищевая промышленность. - 2003. - №3. - С. 10-16.

9. Уголев А.М. Теория адекватного питания и трофология /А.М. Уголев. АН СССР.-СПб.: Наука, 1991. -270 с.

10. Шатнюк Л.Н. Пищевые микроингредиенты в создании продуктов здорового питання / Л.Н. Шатнюк // Пищевые ингредиенты. Сырье и добавки. -2005 . - №2. - C. 18-22.

\section{Глава 2:}

1.Землянухина Н.С. О применении информационных технологий в менеджменте // Успехи современного естествознания. 2012. № 6. С. 106-107.

2.Преображенский Ю.П., Паневин Р.Ю. Формулировка и классификация задач оптимального управления производственными объектами // Вестник Воронежского государственного технического университета. 2010. Т. 6. № 5. С. 99-102.

3.Завьялов Д.В. О применении информационных технологий // Современные наукоемкие технологии. 2013. № 8-1. С. 71-72.

4.Чопоров О.Н., Чупеев А.Н., Брегеда С.Ю. Методы анализа значимости показателей при классификационном и прогностическом моделировании // Вестник Воронежского государственного технического университета. 2008. Т. 4. № 9. С. 92-94. 
5.Москальчук Ю.И., Наумова Е.Г., Киселева Е.В. Проблемы оптимизации инновационных процессов в организациях // Моделирование, оптимизация и информационные технологии. 2013. № 2. С. 10.

6.Гуськова Л.Б. О построении автоматизированного рабочего места менеджера // Успехи современного естествознания. 2012. № 6. С. 106.

7.Пеньков П.В. Экспертные методы улучшения систем управления // Вестник Воронежского института высоких технологий. 2012. № 9. С. 108-110.

8.Исакова М.В., Горбенко О.Н. Об особенностях систем управления персоналом // Вестник Воронежского института высоких технологий. 2014. № 12. С. $168-171$.

9.Самойлова У.А. О некоторых характеристиках управления предприятием // Вестник Воронежского института высоких технологий. 2014. № 12. С. 176179 .

10.Мельникова Т.В. Некоторые особенности работы бизнес-аналитика в IT-сфере // Моделирование, оптимизация и информационные технологии. 2016. № 1. C. 5.

11.Мэн Ц. Анализ методов классификации информации в интернете при решении задач информационного поиска // Моделирование, оптимизация и информационные технологии. 2016. № 2. С. 19.

\section{Глава 3:}

1. Томашевский, В. Т. Машиностроение. Энциклопедия / Ред. совет: К.В. Фролов (пред.) и др. - М.: Машиностроение; СПб.: Политехника. Расчет и конструирование машин. Раздел IV. Корабли и суда. T. IV-20. Общая методология и теория кораблестроения. Кн. 1 [Текст] / В. Т. Томашевский, В. М. Пашин, И. Г. Захаров и др; Под ред. В. Т. Томашевского, В. М. Пашина. СПб.: Политехника, 2003. - 744 с.

2. Пашин, B.M. Оптимизация судов [Текст] / В.М. Пашин. - Л.: Судостроение, 1983. - $296 \mathrm{c.}$

3. Захаров, И. Г. Теория проектирования надводных кораблей [Текст] / И.Г. Захаров, С.И. Постонен, В.И. Романьков. - СПб.: Военно-Морская Академия им. Адмирала Флота Советскою Союза Н.Г.Кузнецова, 1997. - 678 с.

4. Справочник по теории корабля [Текст] : в 3 т. / под ред. Я. И. Войткунского. - Л.: Судостроение, 1985. - Т. 3: Управляемость водоизмещающих судов. Гидродинамика судов с динамическими принципами поддержания. $-542 \mathrm{c.}$

5. Дам Суан Туан. Выбор основных проектных характеристик кораблей береговой охраны [Текст] : дис... канд. техн. наук: 05.08.03 / Украинский гос. морской технический ун-т им. адмирала Макарова ; Украинский государственный морской технический университет имени адмирала Макарова. - Николаев, 2003. - 205 л.: 
6. Некрасов, В.А. Вероятностные задачи мореходности судов [Текст] / В.А. Некрасов. - Л.: Судостроение, 1978. - 300 с.

7. Беляева, М. Учет неопределенность при поиске морских целей [Текст] / М. Беляева // Морской сборник, 1996. - №1. - С. 22-26.

8. Беляева, М. Поиск кораблей в море: от теории к реальности [Текст] / М. Беляева // Морской сборник, 1994. - №7. - С.36-38.

9. Попов, В. Расчет суммарного поискового потенциала [Текст] / В. Попов // Морской сборник, 1995. - №6. - С.28-31.

10. Шпак, В. Комплексное применение средств обнаружения. Модель оценки эффективности [Текст] / В. Шпак, В. Попов // Морской сборник, 1995.№ 6. - C. 27-28.

11. Шпак, В. Оценка эффективности комплексного применения средств обнаружения [Текст] / В. Шпак, В. Попов // Морской сборник, 1995. - № 2. C.28-31.

12. Соломенцев, О.И. Инженерная методика расчета потери скорости на волнении для одно- и двухкорпусных судов. Проектирование судов и судовых устройств [Текст] / О.И. Соломенцев // Сборник научных трудов НКИ. Николаев: НКИ, 1991. - С.45-55.

13. Беляева, М. Теория поиска и здравый смысл [Текст] / М. Беляева // Морской сборник, 2000. - № 4. - С. 28-31.

14. Скворцов, М. О допущениях при оценке эффективности поиска [Текст] / М. Скворцов // Морской сборник, 1995. - № 11. - С.30-31.

15. Вентцель, Е.С. Исследование операций [Текст] / Е.С. Вентцель. - М.: Советское радио, 1972. - 572 с.

16. Ле Куанг Хунг. Определение главных элементов спасательных судов : дис... канд. техн. наук: 05.08.03 / Национальный ун-т кораблестроения им. адмирала Макарова. - Николаев, 2006. - 194 л.

17. Руководство МАМПС: Руководство по международному авиационному и морскому поиску и спасанию. Т. 2: Координация операций [Текст] : издание 2010 г. (с внесенными до конца 2009 года поправками). - Лондон : ИМО ; Монреаль : ИКАО, 2010.

18. Егоров, Г.В. Проектирование судов ограниченных районов плавания на основании теории риска [Текст] / Г.В. Егоров. - СПб.: Судостроение, 2007. $384 \mathrm{c}$.

\section{Глава 4:}

1 Басарыгин Ю.М. Технология бурения нефтяных и газовых скважин: Учеб. для вузов. [Текст] /Ю. М. Басарыгин, А. И. Булатов, Ю. М. Проселков // — М.: ООО «Недра-Бизнесцентр», 2001.

2 Мищенко В.И. Специальное оборудование и технологии циркуляционных систем для бурения вторых стволов и капитального ремонта 
скважин. [Текст] / В. И. Мищенко, Б. В. Мищенко, А. В. Кортунов // Бурение и нефть. - М.: Июнь-Июль, 2012.

3 http://www.slideserve.com.

4 http://www.rbs.ru

5 http://tmc.su

6 Копей Б.В. Параметричний ряд циркуляційних систем мобільних установок для буріння та капітального ремонту [Текст] / Б.В. Копей // Науковий вісник Івано-Франківського національного технічного університету нафти i газу. - Івано-Франківськ: ІФНТУНГ, 2005. - №3 (12) - С.56 - 66.

7 http://www.npoburenie.ru

\section{Глава 5:}

1. Бибило, П. Н. Основы языка VHDL / П. Н. Бибило. - М.: Книжный дом «ЛИБРОКОМ», 2014. - 328 с.

2. Бородин, А. В. Обфускация пула констант как задача построения минимальной системы целочисленных линейных комбинаций / А. В. Бородин, Е. Д. Долгушев // Образование, наука, бизнес: развитие и перспективы: материалы III международной научно-практической конференции (6 мая 2016 г.). - Саратов: Издательство ЦПМ «Академия Бизнеса», 2016. - С. 7-13.

3. Бородин, А. В. Оптимизация стоимости владения объектноориентированной метасистемой в условиях заданной модели угроз / А. В. Бородин // Обозрение прикладной и промышленной математики. - 2006. - Т. 13. - B. 5. - C. 843-844.

4. Бородин А. В. Постановка задачи обфускации пула констант / А. В. Бородин, Е. Д. Долгушев // Новое слово в науке: перспективы развития: материалы IX Международной научно-практической конференции (Чебоксары, 7 авг. 2016 г.). - Чебоксары: ЦНС «Интерактив плюс», 2016. - № 3 (9). - С. 8993.

5. Бородин, А. В. Разработка архитектуры аппаратно-программного комплекса мониторинга тепловой эффективности радиатора водяного отопления / А. В. Бородин, Т. Р. Нафиков // Информационные технологии в жизни современного человека: материалы VI международной научнопрактической конференции (7 апреля 2016 г.). - Саратов: Издательство ЦПМ "Академия Бизнеса", 2016. - С. 27-31.

6. Бородин, А. В. Реконструкция и исследование датчика псевдослучайных чисел в VBA-подсистеме Microsoft Office / A. В. Бородин // NB: Кибернетика и программирование. - 2014. - №4. - C.14-45. - DOI: 10.7256/23064196.2014.4.12648. - URL: http://e-notabene.ru/kp/article_12648.html

7. Бородин, А. В. Феномен компьютерных вирусов: элементы теории и экономика существования / А. В. Бородин. - Йошкар-Ола: Марийский государственный технический университет, 2004. - 144 с. 
8. Варновский, Н. П. Математические проблемы обфускации / Н. П. Варновский, В. А.Захаров, Н. Н. Кузюрин // Труды конференции "Математика и безопасность информационных технологий" (МаБИТ-04), 28-29 октября 2004 г. - М.: Московский Центр Непрерывного Математического Образования, 2004. C. 54-72.

9. Варновский, Н. П. О применении методов деобфускации программ для обнаружения сложных компьютерных вирусов / Н. П. Варновский, В. А. Захаров, Р. И. Подловченко, В. С. Щербина, Н. Н. Кузюрин, А. В. Шокуров // Известия ЮФУ. Технические науки. - 2006. - №7(62). - С. 18-27.

10. Варновский, Н. П. Современное состояние исследований в области обфускации программ: определения стойкости обфускации / Н. П. Варновский, В. А. Захаров, Н. Н. Кузюрин, А. В. Шокуров // Труды Института системного программирования РАН. - 2014. - Т. 26. - В. 3. - С. 167-198.

11. Карпов, К. В. Обеспечение доверенной загрузки приложений, построенных на базе объектной модели Microsoft Excel / К. В. Карпов, А. В. Бородин // Человек, общество, природа в эпоху глобальных трансформаций: безопасность и развитие. Семнадцатые Вавиловские чтения: материалы постоянно действующей международной междисциплинарной конференции. Ч. 2. - Йошкар-Ола: Поволжский государственный технологический университет, 2014. - С. 252-254.

12. Кнут, Д. Искусство программирования для ЭВМ. Т. 2. Получисленные алгоритмы. - М.: Мир, 1977. - 727 с.

13. Коробейников, А. Г. Алгоритм обфускации / А. Г. Коробейников, И. М. Кутузов // NB: Кибернетика и программирование. - 2013. - №3. - C. 1-8. - DOI: 10.7256/2306-4196.2013.3.9356. - URL: http://e-notabene.ru/kp/article_9356.html

14. Коробейников, А. Г. Анализ методов обфускации / А. Г. Коробейников, И. М. Кутузов, П. Ю. Колесников // NB: Кибернетика и программирование. 2012. - №1 . - C. 31-37. - DOI: 10.7256/2306-4196.2012.1.13858. - URL: http://enotabene.ru/kp/article_13858.html

15. Лифшиц, Ю. М. Запутывание (обфускация) программ. Обзор / Ю. М. Лифшиц. - СПб.: Санкт-Петербургское отделение математического института им. В.А. Стеклова РАН., $2004 . \quad-\quad$ URL: http://logic.pdmi.ras.ru/ yura/of/surveyl.pdf.

16. Михеев, Р. Н. VBA и программирование в MS Office для пользователей / Р. Н. Михеев. - СПб.: БХВ-Петербург, 2006. - 384 с.

17. Обфускация (программное обеспечение) // Википедия. Свободная энциклопедия.

URL: https://ru.wikipedia.org/wiki/\%D0\%9E\%D0\%B1\%D1\%84\%D1\%83\%D1\%81\%D0\% BA\%D0\%B0\%D1\%86\%D0\%B8\%D1\%8F_(\%D0\%BF\%D1\%80\%D0\%BE\%D0\%B3 $\% \mathrm{D} 1 \% 80 \% \mathrm{D} 0 \% \mathrm{~B} 0 \% \mathrm{D} 0 \% \mathrm{BC} \% \mathrm{D} 0 \% \mathrm{BC} \% \mathrm{D} 0 \% \mathrm{BD} \% \mathrm{D} 0 \% \mathrm{BE} \% \mathrm{D} 0 \% \mathrm{~B} 5 \_\% \mathrm{D} 0 \% \mathrm{BE} \%$ D0\%B1\%D0\%B5\%D1\%81\%D0\%BF\%D0\%B5\%D1\%87\%D0\%B5\%D0\%BD\%D0 
\%B8\%D0\%B5). Дата обращения: 28.02.2016.

18. Спагетти-код // Википедия. Свободная энциклопедия. - URL: https://ru.wikipedia.org/wiki/\%D0\%A1\%D0\%BF\%D0\%B0\%D0\%B3\%D0\%B5\%D1 $\% 82 \% \mathrm{D} 1 \% 82 \% \mathrm{D} 0 \% \mathrm{~B} 8-\% \mathrm{D} 0 \% \mathrm{BA} \% \mathrm{D} 0 \% \mathrm{BE} \% \mathrm{D} 0 \% \mathrm{~B} 4 . \quad$ Дата обращения: 28.02.2016.

19. Стешенко, В. Б. ПЛИС фирмы Altera: элементная база, система проектирования и языки описания аппаратуры / В. Б. Стешенко. - М.: ДМК Пресс, 2016. - 576 с.

20. Уразаева, Т. А. Алгебра рисков: теория и алгоритмы / Т. А. Уразаева. Йошкар-Ола: Поволжский государственный технологический университет, 2013. - 209 c.

21. Уразаева, Т. А. О функциональности пакета прикладных программ «МультиМИР»/ Т. А. Уразаева // Современные проблемы и перспективы социально-экономического развития предприятий, отраслей, регионов. Йошкар-Ола: Поволжский государственный технологический университет, 2014. - C. 261-265.

22. Уразаева, Т. А. Пакет прикладных программ «МультиМИР»: архитектура и применение / T. А. Уразаева // NB: Кибернетика и программирование. - 2014. - № 5. - C. 34-61. - DOI: 10.7256/23064196.2014.5.12962. - URL: http://e-notabene.ru/kp/article_12962.html.

23. Barak, B. On the (im)possibility of obfuscating programs / B. Barak, O. Goldreich, R. Impagliazzo, S. Rudich, A. Sahai, S. Vadhan, K. Yang // Journal of the ACM. - April, 2012. - Vol. 59. - Iss. 2. - Article No. 6. - 48 p. - DOI: $10.1145 / 2160158.2160159$.

24. Drape, S. Creating transformations for matrix obfuscation / S. Drape, I. Voiculescu // Static Analysis: 16th International Static Symposium, SAS 2009. - Los Angeles, CA: Springer, August, 2009. - P. 273-292. - DOI: 10.1007/978-3-64203237-0_19.

25. Drape, S. Intellectual Property Protection using Obfuscation / S. Drape. Oxford: Oxford University Computing Laboratory. Wolfson Building, Parks Road, March, 2010. - No. RR-10-02. - 51 p. - URL: http://www.cs.ox.ac.uk/files/2936/RR10-02.pdf.

26. Drape, S. The Use of Matrices in Obfuscation / S. Drape, I. Voiculescu. Oxford: Oxford University Computing Laboratory. Wolfson Building, Parks Road, December, 2008. - No. RR-08-12. - 28 p. - URL: http://www.cs.ox.ac.uk/files/1851/RR-08-12.pdf.

27. Garg, S. Candidate indistinguishability obfuscation and functional encryption for all circuits / S. Garg, C. Gentry, S. Halevi, M. Raykova, A. Sahai, B. Waters // 54th Annual Symposium on Foundations of Computer Science, FOCS 2013, October 2013. - Berkeley: IEEE Computer Society, 2013. - P. 40-49. - DOI: 10.1109/FOCS.2013.13. 
28. Goldwasser, S. On best-possible obfuscation / S. Goldwasser, N. R. Guy // Fourth IACR Theory of Cryptography Conference, TCC 2007, February 21-24 2007. - Amsterdam: KNAW Trippenhuis, 2007. - P. 194-213.

29. Ceccato, M. A family of experiments to assess the effectiveness and efficiency of source code obfuscation techniques / M. Ceccato, M. Di Penta, P. Falcarin, F. Ricca, M. Torchiano, P. Tonella // Empirical Software Engineering. 2014. - Vol. 19. - Iss. 4. - P. 1040-1074. - DOI: 10.1007/s10664-013-9248-x.

\section{Глава 6:}

1. Доклад о состоянии безопасности дорожного движения в мире 2013. Поддержать десятилетие действий [Электронный ресурс] // Всемирная организация здравоохранения, Департамент по вопросам предупреждения насилия и травматизма и по инвалидности. - 2013. - Режим доступа: www.who.int/violence_injury_prevention.

2. Australian Bureau of Statistics [Электронный pecypc]. - Режим доступа: www.abs.gov.au.

3. Типове положення про систему управління безпекою руху на автомобільному транспорті (на всіх рівнях - міністерство - підприємство) // Міністерство транспорту України. Наказ від 12 листопада 2003 р. № 877.

4. Безопасность дорожного движения: учебное пособие - 2-е изд., перераб. и доп. / В.В. Амбарцумян, В.Н. Бабанин, О.П. Гуджоян, А.В. Петридис; под ред. В.Н. Луканина. - М.: Машиностроение, 1998. - 304 с.

5. Эльвик Руне. Справочник по безопасности дорожного движения / P. Эльвик, Анне Боргер Мюсен, Трулс Ваа. Пер. с норв. У. Агоповой; под ред. проф. В.В. Сильянова. - М.: МАДИ, 2001. - 746 с.

6. Ротенберг Р.В. Основы надежности системы Водитель-АвтомобильДорога-Среда / Р.В. Ротенберг. - М.: Машиностроение, 1986. - 216 с.

7. Абрамова Л.С. К вопросу надежности транспортных систем / Л.С. Абрамова, Г.Г. Птица // Вестник Харьковского национального автомобильнодорожного университета: сб. науч. тр. - 2009. - Вып. 47. - С.139 - 142.

8. Бабков В.Ф. Дорожные условия и безопасность движения: учебник для вузов / В.Ф. Бабков. - М.: Транспорт, 1993. - 271 с.

9. Абрамова Л.С. Концепція управління безпекою дорожнього руху. Наукові праці. Міжнародна науково-практична конференція, присвячена 85річчю заснування ХНАДУ, 85-річчю автомобільного факультету, а також 3 нагоди Дня автомобіліста та дорожника: «Новітні технології в автомобілебудуванні та на транспорті», 15-16 жовтня 2015 р. / Харківський національний автомобільно-дорожній університет. - Харків, 2015. С.61.

10. Абрамова Л.С. Особенности аудита дорожной безопаности. Автомобильный транспорт: сб. науч. тр., Вып. 36. - Х.: ХНАДУ, 2015. С. 161-165.

11. FHWA Road Safely Audit Guidelines, Federal Highway Administration 
(Федеральная Администрация Автомагистралей, США N FHWA-SA-06-06), Washington, D.C. 2006, 87p.

12. Абрамова Л.С. Аудит безпеки дорожнього руху: підручник / Л.С. Абрамова, І.С. Наглюк, В.В. Ширін, Г.Г. Птиця, С.В. Капінус; під заг. ред. І.С. Наглюка. - Х.: ХНАДУ, 2016. 260 с.

13. Абрамова Л.С. Анализ методов определения показателей безопасности дорожного движения / Л.С. Абрамова, В.В. Ширин, Г.Г. Птица // Вестник Харьковского национального автомобильно-дорожного университета [Текст] : сб. науч. тр. / Харьк. нац. автомоб.-дор. ун-т ; [ редкол.: Богомолов В. А. (глав. ред.) и др.]. - Харьков : ХНАДУ, 2015. - Вып. 69. - С. 118-123.

14. Абрамова Л.С. Классификация методов определения показателей безопасности дорожного движения на автомобильных дорогах / Л.С. Абрамова, Г.Г Птица // Модернизация и научные исследования в транспортном комплексе: материалы международной научно-практической конференции. - Пермь: Пермский национальный исследовательский политехнический университет, 25 27 апреля 2013. - Т. 2 - С. 8-16.

15. Клебельсберг Д. Транспортная психология / Д. Клебельсберг. -М.: Транспорт, 1989. - 367 с.

16. Лукин В.А. Комплексная оценка сравнительного влияния дорожных условий на аварийность отдельных участков автомобильных дорог: дис. кандидата технических наук: 05.23.11 - Москва, 1995. - 217 с.

17. Гаврилов Э. В. Оценка безопасности движения по методу тестирования / Э.В. Гаврилов, С.М. Михович и др. В кн.: Комплексное развитие автомобильного транспорта крупных городов. - М.: Изд. СоюздорНИИ, 1986. С. $178-179$.

18. Сиденко В.М. Комплексный метод оценки безопасности дорожного движения / В.М. Сиденко, А.А. Рыбальченко // Автодорожник Украины, № 3. Киев: Техника, 1978. С. 42-43.

19. Поліщук В.П. Визначення рівнів безпеки руху на автомобільних дорогах загального користування / В.П. Поліщук // Безпека дорожнього руху: правові та організаційні аспекти: VII міжнародна науково-практична конференція, 15-16 листопада 2012 р.: матеріали. - Донецьк, 2012. - С. 226 229. 


\title{
ПЕРСПЕКТИВНЫЕ ТРЕНДЫ РАЗВИТИЯ НАУКИ: ТЕХНИКА И ТЕХНОЛОГИИ
}

\author{
Книга 1 \\ Asmopbl: \\ Львович И.Я. (2.), Некрасов В.А. (3.), Преображенский А.П. (2.), \\ Чопоров О.Н. (2.), Бобось О.Л. (1.), Абрамова Л.С. (6.), \\ Антоненко А.В. (1.), Бондаренко А.В. (3.), Бровенко Т.В. (1.), \\ Копей Б.В. (4.), Птица Г.Г. (6.), Бородин А.В. (5.), \\ Федоляк Н.В. (4.), Довга О.О. (1.), Ліфіренко О.С. (1.), \\ Лях М.М. (4.), Михайлик В.С. (1.), Стукальська Н.М. (1.)
}

Научные достижения Авторов монографии были также рассмотрены и рекомендованы для издания на международном научном Симпозиуме «ПЕРСПЕКТИВНЫЕ ТРЕНДЫ РАЗВИТИЯ НАУКИ»

(20-27 сентября 2016 г.) на сайте www.sworld.education

Монография включена в РИНЦ SCIENCE INDEX

\author{
Формат 60х84/16. Усл печ.лист. 11,57 \\ Тираж 500 экз. Зак. №C16-2. \\ Подписано в печать: 14.10 .2016 \\ Издано: \\ КУПРИЕНКО СЕРГЕЙ ВАСИЛЬЕВИЧ \\ А/Я 38, Одесса, 65001 \\ e-mail: orgcom@sworld.education \\ www.sworld.education \\ Свидетельство субъекта издательского дела ДК-4298 \\ Издатель не несет ответственности за достоверность \\ информации и научные результаты, представленные в монографии \\ Отпечатано с готового оригинал-макета ФЛП Москвин А.А./ Цифровой типографии “Сору-Art” \\ г. Запорожье, пр. Ленина 109
}

